УДК 811.111’373.43

Ю. В. Бережанська

\title{
КОНЦЕПТУАЛЬНА МЕТАФОРА В АНГЛОМОВНОМУ МЕДИЧНОМУ ДИСКУРСІ
}

Бережанська Ю. В. Концептуальна метафора в англомовному медичному дискурсі.

У статті досліджено рекомендації та керівництва 3 лікування алергії й астми Європейської Академії Алергології та Клінічної Імунології (ЕААСІ). Аналізовані тексти виявляють продуктивне функціонування метафоричної моделі ЛІКУВАННЯ ХВОРОБИ Є БОРОТЬБА У ВІЙНІ, яка у свою чергу розгалужується на низку похідних концептуальних метафор.

Ключові слова: концептуальна метафора, медичний дискурс, алергологія, імунологія.

Бережанская Ю. В. Концептуальная метафора в англоязычном медицинском дискурсе.

В статье исследованы рекомендации и руководства по лечению аллергии и астмы Европейской Академии Аллергологии и Клинической Иммунологии (ЕААСІ). Рассматриваемые тексты обнаруживают продуктивное функционирование метафорической модеЛи ЛЕЧЕНИЕ БОЛЕЗНИ ЕСТЬ БОРЬБА В ВОЙНЕ, которая в свою очередь разветвляется на ряд производных концептуальных метафор.

Ключевые слова: концептуальная метафора, медицинский дискурс, аллергология, иммунология.

Berezhanska Yu. V. Conceptual metaphor in the English-speaking medical discourse.

The article examines the recommendations and guidelines for allergy and asthma treatment of European Academy of Allergy and Clinical Immunology (EAACI). The analyzed texts reveal the productive functioning of the metaphorical model TREATING ILLNESS IS FIGHTING A WAR which in turn falls into a number of derivative conceptual metaphors.

Key words: conceptual metaphor, medical discourse, allergology, immunology. 
Вивчення та аналіз концептуальної метафори становить одне 3 провідних завдань сучасної лінгвістики. Теорія концептуальної метафори активно розвивається, постійно набуваючи нових наукових інтерпретацій та переходячи в нові сфери застосування. Сучасне розуміння ролі метафори у процесі номінації полягає в тому, що вона $є$ когнітивним механізмом, за допомогою якого абстрактні поняття осмислюються в більш конкретних термінах. Отже, метафора - це один із фундаментальних прийомів пізнання й концептуалізації дійсності.

Метафори скеровують повсякденну діяльність людини, упорядковують сприйняту нею реальність та способи іiі поведінки у світі. Понятійна система відіграє центральну роль у визначенні повсякденної реальності. Проблемами метафоризації концептів займалися Н. Д. Арутюнова, О. П. Воробйова, Д. Девідсон, М. Джонсон, О. С. Кубрякова, Дж. Лакофф, Е. МакКормак та інші. Американський лінгвіст Джордж Лакофф у своїй фундаментальній студіï «Metaphors We Live Ву» [10] підкреслює, що метафора пронизує наше повсякденне життя, проявляється не тільки в мовленні, але й в мисленні та діях. Учення Дж. Лакоффа та його послідовників отримало назву «теорія концептуальної метафори» («Conceptual Metaphor Theory»), «сучасна теорія метафори» («The Contemporary Theory of Metaphor»). Своїм твердженням, що наша понятійна система, у рамках якої ми мислимо i діємо щодня, $\epsilon$ метафоричною за своєю суттю, Дж. Лакофф підкреслює когнітивну роль метафори [10, с. 3]. На думку Дж. Лакоффа, метафора - це основний механізм, за допомогою якого не тільки усвідомлюються абстрактні концепти, а й забезпечується здатність абстрактно мислити [10, с. 149].

Отже, метафора в когнітивістиці - це спосіб пізнання, концептуалізації і переконцептуалізації дійсності; засіб формування нових понять. Метафора надає змогу осмислити абстрактне в термінах конкретного, вербалізує непредметні поняття через предметні, формуючи нові смисли. Центральна теза Дж. Лакоффа полягає в тому, що метафори полегшують процес мислення, надаючи нам емпіричні рамки, усередині яких ми можемо освоювати новоутворені абстрактні концепти [10, с. 35]. Тим самим поняття впорядковується метафорично, i, отже, мова теж упорядковується метафорично. Докладно аналізує метафору як спосіб мислення в межах когнітивної лінгвістики Е. МакКормак (студія «Когнітивна теорія метафори»), у якій дослідник визначає метафору як пізнавальний процес [4, с. 358-386].

Залежність акту метафоризації від комунікативного фактора $\epsilon$ безсумнівною. Сучасні розробки когнітивної теорії метафори викликані потребою вивчення практичного мовлення й тих сфер, які звернені до мислення, пізнання та свідомості, до концептуальних систем, способів функціонування метафоричних моделей як особливого типу «дискурсивних практик» [1, с. 5-6]. Мова йде про встановлення «емпіричного підгрунтя» 
метафори (у викладі Дж. Лакоффа), тобто узагальненого досвіду взаємодії людини 3 навколишнім світом - із світом об'єктів і соціумом [10, с. 43]. Подібним чином ідеться про комунікативну та когнітивну спрямованість метафоричної номінації в роботах Х. Ортеги-і-Гассета: «Метафора потрібна нам не тільки для того, щоб завдяки отриманому найменуванню зробити нашу думку доступною для інших людей; вона необхідна нам самим для того, щоб об’єкт став доступнішим для нашої думки. Метафора - це не тільки засіб вираження, вона постає важливим знаряддя мислення» [6, с. 71]. О. С. Кубрякова підкреслює: «Нові позначення створюються не тільки для того, щоб фіксувати результати пізнавальної й емоційної діяльності людини, але й для того, щоб зробити ці результати надбанням інших людей» [4, с. 63]. Особливу роль відіграє при цьому досвід безпосередньої взаємодії з матеріальним світом, що відображається в мовних ресурсах, комунікативних актах.

Різноманіття сучасних досліджень у царині концептуальної метафори свідчить про зростаючий інтерес до теорії Дж. Лакоффа і М. Джонсона. Твердження про те, що концептуальні метафори охоплюють усю сферу людського досвіду i володіють значним когнітивним потенціалом, на сьогоднішній момент підкріплюється численними дослідженнями, що практично охоплюють більшість сфер людської діяльності. Особливого поширення набули дослідження концептуальної метафори у сфері політичної комунікації [2, с. 25].

Водночас роль концептуальної метафори в медичному дискурсі вивчена недостатньо, що й спонукає нас звернутися до цієї проблеми. Матеріалом дослідження послугували рекомендації та керівництва з лікування алергії й астми Європейської Академії Алергології та Клінічної Імунології (European Academy of Allergology and Clinical Immunology (EAACI), що містяться в електронній базі даних медичних публікацій «PubMed». «Європейська декларація з імунотерапії» (2011) й інші документи Академії розроблені провідними європейськими вченими задля того, аби скоординувати й об'єднати зусилля лікарів, пацієнтів, менеджерів у галузі охорони здоров'я та політиків для підвищення якості лікування пацієнтів, які страждають на алергічні захворювання. Беручи до уваги епідеміологічні тенденції сьогодення, за підрахунками фахівців Свропейської Академії Алергології та Клінічної Імунології, менш ніж через 15 років більше половини населення Свропи страждатиме від тієї чи тієї алергічної патології. Чітка прагматична спрямованість документів Європейської Академії, плюралізм стратегій подолання алергії, яка нині набуває пандемічних масштабів, зумовили вибір аналізованих текстів.

Мета статті - дослідити особливості функціонування концептуальних метафор в англомовному медичному дискурсі, присвяченому проблемам лікування алергії, та проаналізувати їх вербальне втілення. Результати 
дослідження можуть бути використані в навчанні англійської мови студентів вищих медичних навчальних закладів. Мовний опис професійного спілкування лікаря з пацієнтом є важливим елементом підготовки лікарів та оптимізації їхньої діяльності.

Для англомовного медичного дискурсу з проблематики імунології й алергології характерною є взаємодія концептуальних сфер ВІЙНА («target domain» - царина джерела, тобто концепт, за допомогою якого ми намагаємося зрозуміти аналізоване поняття) та ХВОРОБА («target domain»- царина мети, тобто поняття, яке ми намагаємося зрозуміти). У результаті цього співвіднесення утворюється концептуальна метафорична модель ЛІКУВАННЯ ХВОРОБИ Є БОРОТЬБА У ВІЙНІ (TREАТІNG ILLNESS IS FIGHTING A WAR): «allergies constitute a public health concern of pandemic proportions requiring immediate action» [8, c. 5]; «steps are taken to strengthen the treatment strategies» [11, c. 1526]; 《awareness campaigns and patient educational programs» [9, c. 304]; «a cure of the disease must be the target for researches» [9, c. 301]. В англомовному медичному дискурсі 3 проблематики імунології й алергології ця метафорична модель розгалужується на низку похідних концептуальних метафор, які отримують у текстах широке мовне втілення.

Концептуальна метафора ХВОРОБА Є ВОРОГОМ (THE DISEASE IS AN ENEMY) спостерігається як у дискурсі медичних фахівців: «patients face a relentless impairment» [8, c. 11]; «allergic patients suffer from severe and debilitating disease» [11, с. 1528], так і в дискурсі нефахівців (пацієнтів): «food allergy is a nightmare» [9, с. 305].

Неабиякого поширення набуває в медичному дискурсі, присвяченому проблемам імунології й алергології, комплекс метафор ДІї ХВОРОБИ Є ЗАХОПЛЕННЯМ ТЕРИТОРIÏ (DISEASE'S ACTIONS ARE INVASION OF THE TERRITORY); ТІЛО Є МІСЦЕМ ВОЄННИХ ДІЙ (ТНЕ ВОDY IS A BATTLEGROUND) та ВIPУC Є AТАКОЮ ЗІ СТОРОНИ ХВОРОБИ (VIRUS IS AN ATTACK BY THE DISEASE): «the skin plays a major role in allergy by acting as the first frontier of the body to allergen contact and sensitization» [7, c. 2802]; 《an intact epidermal barrier protects the immune system» [7, c. 2815]; «an impairment of the skin barrier <.. > allows allergen penetration» [7, с. 2821]. Концептуальна метафора ХВОРОБА Є ВОРОГОМ стимулює осмислення пацієнтом сутності хвороби і наводить на думку, що будь-якого ворога зрештою можна подолати за допомогою зброї, певної тактики. У цьому контексті актуалізується концептуальна метафора ЛІКИ Є ЗБРОЄЮ (РЯТІВНИКОМ) (MEDICINE IS A WEAPON (SAVER): «venom immunotherapy is $98 \%$ successful $<\ldots>$ and is a life saver in the venom sensitive patients» $[8$, c. 14$]$.

Зрештою, дискурс виявляється пронизаний метафорою ВИЛІКУВАТИСЬ ВІД ХВОРОБИ - ПЕРЕМОГТИ У ВІЙНІ (BEING CURED OF ТНЕ 
DISEASE IS WINNING THE WAR): «combating allergy beyond symptoms» [9, c. 302]; «fighting allergy and its symptoms» [7, c. 2802].

Дослідження механізмів метафоричної концептуалізації уможливило реконструювання метафор, які формують стереотипне сприйняття перебігу та лікування хвороби як війни в англомовному медичному дискурсі 3 проблематики імунології й алергології. Результати дослідження свідчать про те, що зазначені концептуальні метафори отримують широке мовне втілення в англомовному медичному дискурсі, присвяченому проблемам лікування алергії. Метафори постають невід'ємною частиною медичного дискурсу, певним напрямком руху несвідомої творчої активності медика, беручи участь у створенні «інваріантного професійного образу світу» [3, с. 141]. Отже, метафора в медичному дискурсі, присвяченому проблемам лікування алергії, - це система, при взаємодії абстрактного й конкретного компонентів якої виникає нове значення, новий спосіб репрезентації стану пацієнта i шляхи його поліпшення. Концептуальна метафора в медичному дискурсі виконує функцію призми, через яку лікар і пацієнт сприймають навколишню дійсність, тлумачать хворобу як абстрактного ворога, якому слід кинути виклик. Метафора - це один зі способів установлення контакту з пацієнтом, запорука взаєморозуміння між лікарем i пацієнтом. Перспективним $\epsilon$ подальше дослідження та конкретизація типології концептуальних метафор у межах медичного дискурсу з проблем імунології й алергології.

\section{Література}

1. Арутюнова Н. Д. Язык и мир человека / Н. Д. Арутюнова. - М. : Языки русской культуры, 1999. - 326 с.

2. Будаев Э. В. Становление когнитивной теории метафоры / Э. В. Будаев // Лингвокультурология. - 2007. - Вып. 1. - С. 16-32.

3. Зубкова О. Медицинская метафора - термин в индивидуальном лексиконе (экспериментальное исследование) / О. Зубкова // Знание. Понимание. Умение. 2010. - Вып. 1. - С. 140-145.

4. Кубрякова Е. С. Язык и знание. На пути получения знаний о языке : части речи с когнитивной точки зрения. Роль языка в познании мира / Е. С. Кубрякова. - М. : Языки славянской культуры, 2004. - 560 с.

5. МакКормак Э. Когнитивная теория метафоры / Эрл Мак Кормак // Теория метафоры : сборник : пер. с англ., фр., нем., исп., пол. яз. - М. : Прогресс, 1990. C. $358-386$.

6. Ортега-и-Гассет Х. Две великие метафоры / Х. Ортега-и-Гассет // Теория метафоры : сборник : пер. с англ., фр., нем., исп., пол. яз. - М. : Прогресс, 1990. - С. 68-81.

7. Akdis C. Fighting Allergies Beyond Symptoms : The European Declaration on Immunotherapy / C. Akdis, N. Papadopoulos, V. Cardona // European Journal of Immunology. - 2011. - Vol. 41 (10). - P. 2802-2834.

8. Calderon M. A. EAACI : A European Declaration on Immunotherapy. Designing the Future of Allergen Specific Immunotherapy / M. A. Calderon, P. Demoly, R. Gerth van Wijk // Clin Transl Allergy. - 2012. - 2 (1). - P. 2-20.

9. Calderon M. A. European Academy of Allergy and Clinical Immunology. 
Perspectives on Allergen-Specific Immunotherapy in Childhood : an EAACI Position Statement / M. A. Calderon, R. Gerth van Wijk, I. Eichler // Pediatr Allergy Immunol. 2012. - Vol. 23 (4). - P. 300-306.

10. Lakoff G. Metaphors We Live By / George Lakoff, Mark Johnson. - Chicago : University of Chicago Press, 1980. - 242 p.

11. Zuberbier T. GA² LEN/EAACI Pocket Guide for Allergen-Specific Immunotherapy for Allergic Rhinitis and Asthma / T. Zuberbier, C. Bachert, P. J. Bousquet // Allergy. 2010. - Vol. 65 (12). - P. 1525-1530. 